\section{Shiga toxin-producing Escherichia coli in slaughtered pigs and pork products}

\author{
Lia Bardasi, Roberta Taddei, \\ Ilaria Fiocchi, \\ Maria Francesca Pelliconi, Mattia \\ Ramini, Elena Toschi, \\ Giuseppe Merialdi \\ Institute for Experimental Veterinary \\ Medicine of Lombardy and Emilia \\ Romagna, Bologna, Italy
}

\begin{abstract}
During the years 2015-2016, 83 faecal samples were collected at slaughter from pigs reared in farms located in CentralNorthern Italy. During the years 2014-2016 a total of 562 pork products [465 not-readyto-eat (NRTE) and 97 ready-to-eat (RTE) products] were collected from retail outlets, large retailers and processing plants. The samples were analysed according to ISO TS 13136:2012. Out of 83 swine faecal samples, $77(92.8 \%)$ resulted stx-positive by real time polymerase chain reaction (PCR), 5 st $x 2+$ and 1 stx $1+$ Shiga toxin-producing Escherichia coli (STEC) strains were isolated. Among the 465 NRTE samples, 65 $(14.0 \%)$ resulted stx-positive by real time PCR and 7 st $x 2+$ STEC strains were isolated. The stx2 gene was detected more frequently than the stxl gene both in faecal samples (90.4 vs 8.4\%) and in NRTE pork products (13.3 vs 1.3\%). All the RTE samples included in the analysis resulted stxnegative. Among the samples resulted positive for stx and eae genes, serogroup-associated genes were detected at high frequency: O26 resulted the most frequent in faecal samples $(81.3 \%)$ and $\mathrm{O} 145$ in pork products (88.1\%). The O157 serogroup resulted positive in 83.3 and $78.1 \%$ of pork products and faecal samples, respectively. Despite the frequent detection by real time PCR of genes indicating the possible presence of STEC strains belonging to the six serogroups, the bacteriological step did not confirm the isolation of any such strains.
\end{abstract}

\section{Introduction}

Shiga toxin-producing Escherichia coli (STEC) are a group of highly pathogenic foodborne zoonotic pathogens, causing diarrhea, hemorrhagic colitis (HC), and hemolytic uremic syndrome (HUS) in humans. The common feature and main vir- ulence factors of STEC are two phageencoded cytotoxins, called Shiga toxins (stx1 and stx2), which are directly correlated with human pathogenicity (Lindgren et al., 1993). Adherence factors are also critical features of STEC pathogenicity: human pathogenic STEC known to cause severe intestinal disease can attach to intestinal epithelial cells and form attaching and effacing lesions through an outer membrane protein called intimin, which is encoded by the eae gene. Furthermore, as shown by the enteroaggregative E. coli (EAEC) O104:H4 strain that caused the large outbreak in Germany in 2011, other means of attachment such as the factors coded by the aggR regulatory plasmid gene and the chromosomal aaiC gene, when coupled with the production of $s t x 2$, can have severe consequences (Beutin and Martin, 2012). More than 200 virulent STEC serotypes have been isolated from human infections (Coombes et al., 2008). Although E. coli O157: H7 is the serotype that has been linked to most outbreaks of food-borne diseases and brought the largest number of cases of HUS, in recent years a growing number of non-O157 STEC strains have been isolated from human clinical cases and outbreaks (Caprioli et al., 2005). The lower intestinal tract of ruminants is considered to be the main natural reservoir of STEC. In most human infections, transmission occurs primarily by ingestion of contaminated food of bovine origin, though few outbreaks have been associated to the consumption of other food products, including pork products contaminated by $\mathrm{O} 157$ (CDC, 1995; Williams et al., 2000; MacDonald et al., 2004; Conedera et al., 2007; Trotz-Williams et al., 2012; Honish et al., 2017) and by O111 (Paton et al., 1996). However, the epidemiology and virulence characteristics of STEC carried by on-farm pigs remain largely unknown. The hypothesis that swinederived STEC strains are similar to humanderived STEC strains and have the potential to contribute to human infections needs to be further investigated (Tseng et al., 2014a).

Unfortunately, epidemiological data on STEC prevalence in pigs and in food products made of pork are collected at the European level only by a few countries and they are not always comparable (EFSA and ECDC, 2016). Following E. coli O104:H4 outbreak occurred in Germany in May 2011, Emilia Romagna Region instituted in 2012 a testing program for O157, O26, O111, O103, O145 and O104:H4 STEC, both at production and at retail level, for foodstuff considered at risk of contamination. During years 2012-2013 monitoring plan STEC virulence genes were detected at high frequency (19\%) in fresh pork sausage
Correspondence: Lia Bardasi, Institute for Experimental Veterinary Medicine of Lombardy and Emilia Romagna, via Pietro Fiorini 5, 40127 Bologna, Italy.

Tel: +39.051.4200037 - Fax: +39.051.4200038

E-mail: lia.bardasi@izsler.it

Key words: Shiga toxin-producing Escherichia coli; Pig; Pork meat; Pork products.

Received for publication: 19 January 2017. Revision received: 31 March 2017.

Accepted for publication: 31 March 2017

This work is licensed under a Creative Commons Attribution-NonCommercial 4.0 International License (CC BY-NC 4.0).

(C) Copyright L. Bardasi et al., 2017

Licensee PAGEPress, Italy

Italian Journal of Food Safety 2017; 6:6584

doi:10.4081/ijfs.2017.6584

and one verocytotoxic E. coli $\mathrm{O} 103$ strain was isolated from pork meat (Bardasi et al., 2015).

Because of the limited epidemiologic data on STEC prevalence in swine, the increasing evidence of pork food STEC contamination, and the rising role of nonO157 STEC in human outbreaks, the aim of this study is to investigate on STEC occurrence both in caecal content samples collected from pigs to the slaughterhouse and from pork food products.

\section{Materials and Methods}

During the years 2015 and 2016, 83 swine individual faecal samples were collected from the rectum of animals at slaughter in Emilia Romagna Region. Swine were reared in 18 different farms located in Piedmont, Emilia Romagna, Tuscany and Lombardy, 1 to 7 swine from each farm were included.

A total of 562 pork products were collected during January 2014 to August 2016 in Emilia Romagna Region from retail outlets, large retailers and processing plants. Food samples comprised 465 not-ready-toeat (NRTE) products to be consumed after cooking (62 pork meat, 109 pork minced meat, 294 fresh meat pork sausages and processed meat products) and 97 ready-toeat (RTE) samples (65 salami, 26 dry-cured ham, 2 mortadella, 2 pancetta, 2 coppa)

The samples were analysed according to ISO TS 13136:2012 (ISO, 2012); $25 \mathrm{~g}$ of each food sample were diluted ten-fold $(\mathrm{w} / \mathrm{v})$ in modified Tryptone Soya Broth (mTSB) supplemented with $16 \mathrm{mg} / \mathrm{L}$ of 
novobiocin $(\mathrm{mTSB}+\mathrm{N})$ and incubated at $37 \pm 1^{\circ} \mathrm{C}$ for $21 \pm 3 \mathrm{~h}$. Five grams of each faecal sample was diluted ten-fold (w/v) in Tryptone Soya Broth and incubated at $37 \pm 1^{\circ} \mathrm{C}$ for $21 \pm 3 \mathrm{~h}$. Bacterial DNA was extracted from $1 \mathrm{~mL}$ of enriched broth using Gen elute ${ }^{\mathrm{TM}}$ bacterial genomic DNA kit (Sigma-Aldrich, St. Louis, MO, USA) as described by the manufacturer. All primers and probes used in this study are reported in ISO 13136:2012 and published previously (Perelle et al., 2004; Nielsen and Andersen, 2003; ISO, 2012). Multiplex real time polymerase chain reaction (PCR) targeting the virulence genes eae, stx 1 and stx2 was conducted in a $25 \mu \mathrm{L}$ reaction volume using the following reaction mixture: $1 \mathrm{X}$ Taqman ${ }^{\circledR}$ Universal PCR Master mix (Applied Biosystems, Foster City, CA, USA), $450 \mathrm{nM}$ each of the forward and reverse primers, $100 \mathrm{nM}$ of each labeled probe and $4 \mu \mathrm{L}$ DNA template. A commercially available $\operatorname{TaqMan}^{\circledR}$ Exogenous Internal Positive Control (Applied Biosystems) was included in each PCR reaction. Real time-PCR thermal cycling was conducted using a StepOne Plus system (Applied Biosystems). The cycling parameters were: $95^{\circ} \mathrm{C}$ hold for $10 \mathrm{~min}$ for initial denaturation of the DNA and activation of the hot-start Taq polymerase, followed by 40 cycles of amplification of $95^{\circ} \mathrm{C}$ for $15 \mathrm{~s}$, and $60^{\circ} \mathrm{C}$ for $60 \mathrm{~s}$. Samples resulted positive for the presence of stx 1 and/or stx 2 gene were tested for E. coli O104 serogroupassociated gene. Sample positive for the presence of stx 1 and/or stx2 in association with eae gene were tested for the detection of E. coli O103, O111, O145, O157, O26, serogroup-associated genes. Serogroup specific PCR reactions were conducted in a 25 $\mu \mathrm{L}$ reaction volume using the following reaction mixture: $1 \mathrm{X}$ Taqman ${ }^{\circledR}$ Universal PCR Master mix (Applied Biosystems), $900 \mathrm{nM}$ each of the forward and reverse primers, $250 \mathrm{nM}$ of the labeled probe and 4 $\mu \mathrm{L}$ DNA template. The PCR instrument and program were the same used for the previous reaction. When stx 1 and/or stx 2 genes were detected, the isolation of the strain from the enrichment sample broth was attempted. Enriched samples were plated on Tryptone Bile X-Glucuronide (TBX) agar and incubated for $18-24 \mathrm{~h}$ at $37 \pm 1^{\circ} \mathrm{C}$. Up to 50 colonies with $E$. coli morphology were picked up and point-inoculated on Nutrient agar (NA). Pools of 10 colonies were tested by real time PCR for the presence of virulence genes eae, stx 1 and stx2, afterward colonies from positive pools were tested singularly in order to identify STEC strain.

STEC stains without eae gene were tested for the presence of aaiC and $a g g R$ genes by real time PCR assay described by EU Reference Laboratory for E. coli (EURL VTEC, web site: http://www.iss.it/binary/vtec/cont/EU_RL_VTEC_Method_05_ Rev_1.pdf).

\section{Results}

Out of a total of 83 swine faecal samples tested by real time PCR for the presence of stx 1 , stx 2 and eae, $92.8 \%(77 / 83)$ resulted stx-positive with $s t x 2$ gene more frequently detected than the stxl gene (75/83 equals to $90.4 \%$ vs $7 / 83$ equals to $8.4 \%)$. Two out of $83(2.4 \%)$ samples tested positive for stxl associated with eae gene, 13/83 samples (15.7\%) resulted positive only for the stx2 gene, 57/83 (68.7\%) tested positive for the stx 2 gene in association with eae gene and 5/83 samples $(6.0 \%)$ resulted positive for stx 1 , stx 2 and eae (Table 1). Serogroup O26, O103, O104,
O111, O145 and O157 and associated genes were detected respectively in 52/64 (81.3\%), 51/64 (79.7\%), 48/77 (62.3\%), 23/64 (35.9\%), 51/64 (79.7\%) and 50/64 (78.1\%) faecal samples. Out of a total of 562 pork products tested, no one of the 97 RTE sample resulted positive for stx genes and among the 465 NRTE samples, 65 $(14.0 \%)$ resulted stx-positive. The stx 2 gene was detected more frequently than the stx 1 gene $(62 / 465$ equals to $13.3 \%$ vs $6 / 465$ equals to $1.3 \%$ ). One sample out of 465 $(0.2 \%)$ resulted positive only for stx 1 gene, 2/465 (0.4\%) samples were positive for stx 1 associated with eae gene, 22/465 (4.7\%) samples tested positive only for stx 2 gene, $37 / 465(8.0 \%)$ were positive for the stx 2 gene in association with eae gene and $3 / 465$ $(0.7 \%)$ samples resulted positive for stx 1 , stx2 and eae. Serogroup O26, O103, O104, O111, O145 and O157 associated genes were detected respectively in $32 / 42$ (76.2\%), 19/42 (45.2\%), 5/65 (7.7\%), 8/42 $(19.0 \%), 37 / 42(88.1 \%)$ and $35 / 42(83.3 \%)$ NRTE pork samples.

Among the samples tested for O-group associated genes, $87.5 \%(56 / 64)$ faecal samples and $90.5 \%$ (38/42) food samples resulted positive to more than one serogroup. Percentages of samples tested simultaneously positive to 1 up to 6 serogroups are reported in Table 2.

Table 1. Detection of virulence genes and O-group associated genes in swine faecal samples and in food pork samples.

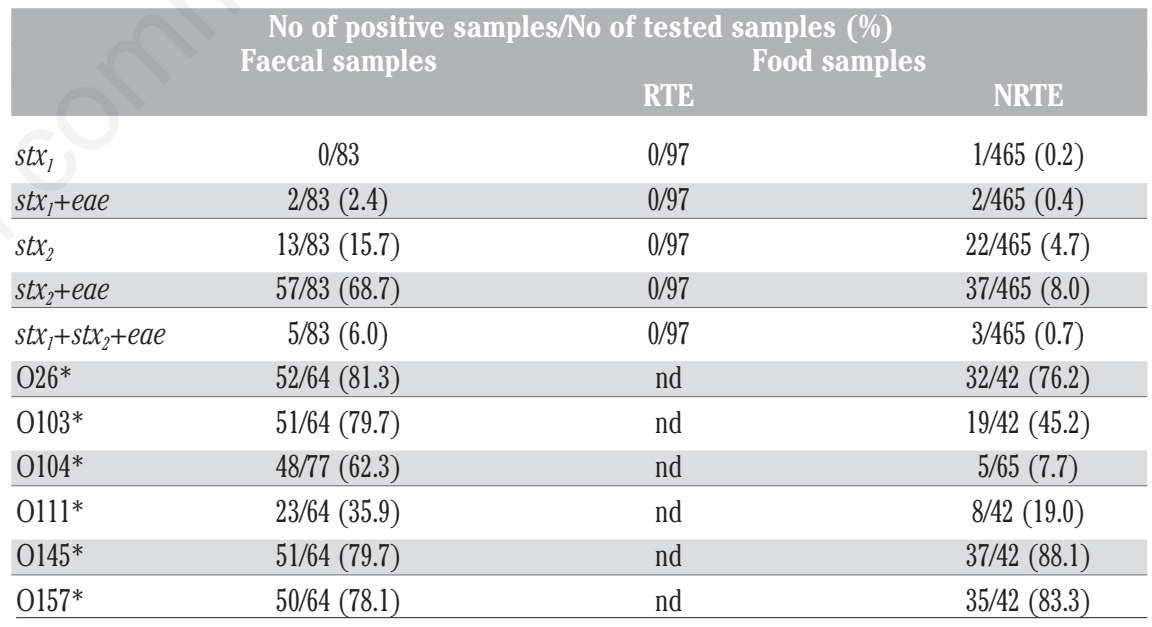

RTE, ready to eat; NRTE, not ready to eat; nd, not done. ${ }^{*}$ The percentage are calculated $v$ s the number of samples subjected to analysis according to ISO/TS13136, i.e. the number of samples positive for $s t x_{l}$ and/or $s t x_{2}$ genes for 0104 serogroup and the number of samples positive for $s t x_{l}$ and/or $s t x_{2}$ genes in association with eae gene for the remaining serogroups.

Table 2. Not ready to eat food products and faecal samples positive to one or more serogroups.

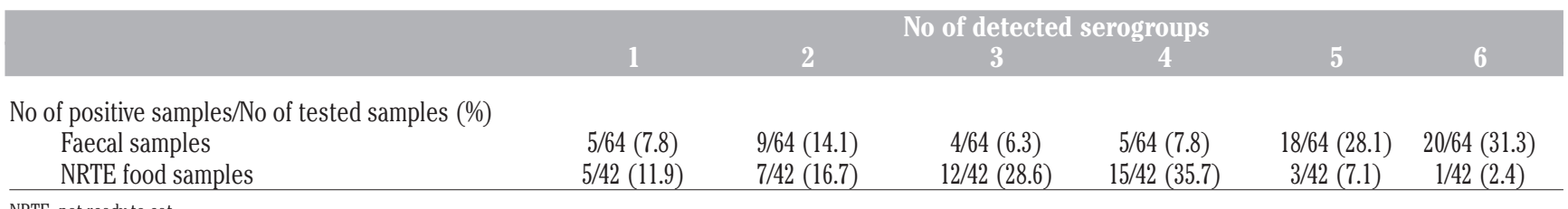

NRTE, not ready to eat. 
Six STEC strains were isolated from faecal samples giving a culture positive STEC rate of $7.8 \%(6 / 77)$ for stx-positive samples and $7.2 \%(6 / 83)$ for all samples: one $s t x 1+$ strain and 5 stx $2+$ strains were isolated, two strains stx $2+$ being isolated from swine reared in the same farm.

Seven STEC strains were isolated from NRTE food samples giving a culture positive STEC rate of $10.8 \%(7 / 65)$ for stx-positive samples and 1.5\% (7/465) for all samples. The strains were all st $x 2+: 4$ were isolated from minced meat and 3 from fresh sausages. None of the isolated STEC strains belonged to one of the Top five or $\mathrm{O} 104$ serogroups. None of the isolated strains carried $a g g R$ and $a a i C$ genes.

\section{Discussion}

Epidemiological studies performed in European countries have reported a STEC contamination rates in faecal samples of slaughtered pigs estimates by PCR for $s t x$ genes of $22 \%$ out of 630 samples analysed in Switzerland (Kaufmann et al., 2006), $23.8 \%$ (24/101) in Belgium (Botteldoorn et al., 2002), 31\% (56/182) in France (Bouvet et al., 2002) and $38.6 \%(81 / 210)$ in Italy, Umbria and Marche regions (Ercoli et al., 2016) with a STEC isolation rate ranging from 7.9\% (8/101) (Botteldoorn et al., $2002)$ to $12.4 \%(26 / 210)$ (Ercoli et al., 2016). In Germany and Italy, swine population has been investigated resulting in $10.1 \%$ of 475 animals and none of 102 animals positive for STEC isolation, respectively (EFSA and ECDC, 2016). In our study, 92.8\% (77/83) swine faecal samples resulted stx-positive, and a STEC isolate was recovered in $7.2 \%(6 / 83)$ of samples. STEC contamination rate assessed by real time PCR for stx genes resulted higher while the isolation rate resulted comparable to that reported in other European countries. However, it is very difficult to make comparisons among different studies since sampling collection method, sample size, geographic location and different protocols applied for STEC PCR detection and isolation can significantly influence the results (Fratamico et al., 2004; Tseng et al., 2014b). As reported by EFSA and ECDC (2016), 859 samples of pork meat have been tested in EU during 2015 by ISO13136:2012 with a STEC isolation rate of $2.56 \%(22 / 859)$. In Italy STEC contamination rate in fresh pork sausages assessed by PCR for stx-genes varied from $16 \%$ (20/126) (Villani et al., 2005) to $19 \%$ (41/213) (Bardasi et al., 2015) and the analysis of 675 samples including both fresh and dried products revealed 19 (2.8\%) stx-positive fresh sausage samples (Ercoli et al., 2016). The STEC isolation rate ranged from $0 \%$ (Ercoli et al., 2016) to $10 \%$ $(13 / 126)$ (Villani et al., 2005). In this study, no one of 97 RTE samples and 65 (14.0\%) of 465 NRTE samples resulted stx positive by real time PCR with an isolation rate of $1.5 \%(7 / 465)$ among NRTE samples.

It is worth highlighting that all the 97 RTE samples included in the analysis resulted stx-negative. Various production processes were comprised in the panel of the RTE tested samples: heat-curing (mortadella), dry-curing (ham, pancetta and coppa), curing of fermented and air-dried meat (salami). Our data indicate that these manufacturing processes may have rendered the tested samples safe with respect to contamination by STEC.

As reported by EFSA and ECDC (2016), among the 859 samples of pork meat tested in EU in 2015 one O157 STEC strain $(0.12 \%)$ and no O26, O103, O145, O111 STEC strains were isolated. Ercoli et al. (2016), reported high percentage of detection of Top five serogroup associatedgenes both in pork samples (O157: 42.1\%, O145: 94.7\%, O103: 78.9\%, O26: 36.8\%) and in swine faecal samples (O157: 86.4\%, O145: 9.9\%, O103: 17.3\%, O26: 38.3\%, O111: $1.2 \%$ ), but no STEC strains belonging to these serogroups has been isolated.

Verocytotoxin-producing E. coli $\mathrm{O} 157$ has been isolated from swine faecal samples at low frequencies in Europe, ranging from $0 \%(0 / 630)$ in Switzerland (Kaufmann et al., 2006), France (0/182) (Bouvet et al., 2002), Belgium (0/101) (Botteldoorn et al., 2003) and United Kingdom (0/1000) (Chapman et al., 1997), 0.08\% (2/2446) in Sweden (Eriksson et al., 2003), 0.1\% (2/1976) in Norway (Johnsen et al., 2001) and $0.7 \%(1 / 150)$ in Italy (Bonardi et al., 2003).

The genes associated with the top five and $\mathrm{O} 104$ serogroups were detected at high frequency in this study, in particular O26, O145 and O157 serogroups resulted positive with high percentage in both faecal and food samples. O26 resulted the most frequent serogroup in faecal samples $(81.3 \%$ of the stx and eae positive samples) and O145 in pork products $(88.1 \%$ of the stx and eae positive samples). The $\mathrm{O} 157$ serogroup resulted positive in $78.1 \%$ and $83.3 \%$ of the faecal samples and pork samples tested for O-group associated genes, respectively. Furthermore, 61 out of the $64(95.3 \%)$ faecal samples and all the 42 pork samples tested for the six serogroups (O26, O103, O104, O111, O145 and O157) resulted contaminated with one or more serogroups, the higher percentage of samples being positive to all six serogroups in faecal samples and to four serogroups in pork products. Nevertheless STEC strains belonging to the six serogroups have not been isolated in this study. Additionally, neither strains harboring both stx and eae genes, nor strains harboring stx gene in association with aaiC and aggR genes, have been isolated. The characteristics of the isolated strains indicate that the virulence and the serogroups-associated genes detected at high frequencies by real time PCR in the enriched samples, are presumably located on different bacterial strains. This hypothesis is also supported by the isolation from faecal samples of 19 strains belonging to O26, O103, O145, O111 and O104 serogroups ( 5 belonging to serogroup O26, 3 to O103, 2 to O104, 1 to O111, 8 to O145, none to serogroup O157) but not characterised by the presence of the stx and/or eae genes and of two E. coli strains only harboring the eae gene. An extensive study carried out in U.S.A. on 181 STEC strains recovered from swine faecal samples reported comparable results: none of the STEC strains characterised by molecular methods carried eae gene or belonged to O26, O103, O111, O157 and O104 serogroups, only one strain being positive to $\mathrm{O} 145$ serogroup-associated gene (Baranzoni et al., 2016).

According to the molecular classification scheme proposed by EFSA (2013) STEC can be categorised according to potential risk for consumers health as group I (high potential risk) through to group III (unknown risk). An isolate of STEC serogroups O157, O26, O103, O145, O111, $\mathrm{O} 104$ in combination with stx and eae or aaiC and aggR genes (group I) should be considered as presenting a potentially high risk for diarrhoea and HUS. For any other serogroups in combination with the same genes (group II), the potential risk is regarded as high for diarrhoea, but currently unknown for HUS. In the absence of these genes (group III), there is uncertainty whether or not they are able to cause disease and a scientific judgement based on current knowledge of virulence characteristics cannot be done (EFSA, 2013). Remarkably, the STEC strains isolated in this study all belong to group III. Actually, swine are not viewed as an important STEC reservoir given the rare incidence of cases of severe human illness associated with STEC of swine origin (Tseng et al., 2014b).

\section{Conclusions}

In conclusion, in this study STEC stains have been isolated both in swine feces at slaughter and in NRTE pork products, while all RTE samples resulted st $x$-negative. The 
isolated strains are not the ones correlated with high risk for diarrhoea and HUS; nevertheless their human pathogenic potential is not yet fully defined.

\section{References}

Baranzoni GM, Fratamico PM, Gangiredla J, Patel I, Bagi LK, Delannoy S, Fach P, Boccia F, Anastasio A, Pepe T, 2016. Characterization of shiga toxin subtypes and virulence genes in porcine shiga toxinproducing Escherichia coli. Front Microbiol 21:574.

Bardasi L, Taddei R, Nocera L, Ricchi M, Merialdi G, 2015. Shiga toxin-producing Escherichia coli in meat and vegetable products in Emilia Romagna Region, years 2012-2013. Ital J Food Safety 4:4511.

Beutin L, Martin A, 2012. Outbreak of Shiga toxin producing Escherichia coli (STEC) O104:H4 infection in Germany causes a paradigm shift with regard to human pathogenicity of STEC strains. J Food Protect 75:408-18

Bonardi S, Brindani F, Pizzin G, Lucidi L, D'Incau M, Liebana E, Morabito S, 2003. Detection of Salmonella spp., Yersinia enterocolitica and verocytotoxin producing Escherichia coli O157 in pigs at slaughter in Italy. Int $\mathrm{J}$ Food Microb 85:101-10.

Botteldoorn N, Heyndrickx M, Rijpens N, Herman L, 2002. Detection and characterization of verotoxigenic Escherichia coli by a VTEC/EHEC multiplex PCR in porcine faeces and pig carcass swabs. Res Microbiol 154:97-104.

Bouvet J, Montet MP, Rossel R, Le Roux A, Bavai C, Ray-Gueniot S, Mazuy C, Atrache V, Vernozy-Rozand C, 2002. Effects of slaughter processes on pig carcass contamination by verotoxin-producing Escherichia coli and E. coli O157:H7. Int J Food Microbiol 77:99-108.

Caprioli A, Morabito S, Brugère H, Oswald E, 2005. Enterohaemorrhagic Escherichia coli: emerging issues on virulence and modes of transmission. Vet Res 36:289311.

CDC, 1995. Escherichia coli O157:H7 outbreak linked to commercially distributed dry-cured salami - Washington and California, 1994. MMWR Morb Mortal Wkly Rep 44:157-60.

Chapman PA, Siddons CA, Gerdan Malo AT, Harkin MA, 1997. A 1-year study of Escherichia coli O157 in cattle, sheep, pigs and poultry. Epidemiol Infect 119:245-50.

Conedera G, Mattiazzi E, Russo F, Chiesa E, Scorzato I, Grandesso S, Bessegato A, Fioravanti A, Caprioli A, 2007. A family outbreak of Escherichia coli O157 haemorrhagic colitis caused by pork meat salami. Epidemiol Infect 135:311-4.

Coombes BK, Wickham ME, Mascarenhas M, Gruenheid S, Finlay BB, Karmali MA, 2008. Molecular analysis as an aid to assess the public health risk of non-O157 Shiga toxin-producing Escherichia coli strains. Appl Environ Microb 74:2153-60.

EFSA, 2013. Scientific opinion on VTECseropathotype and scientific criteria regarding pathogenicity assessment. EFSA J 11:1-106.

EFSA, ECDC, 2016. The European Union summary report on trends and sources of zoonoses, zoonotic agents and food-borne outbreaks in 2015. EFSA J 14:4634.

Ercoli L, Farneti S, Zicavo A, Mencaroni G, Blasi G, Striano G, Scuota S, 2016. Prevalence and characteristics of verotoxigenic Escherichia coli strains isolated from pigs and pork products in Umbria and Marche regions of Italy. Int J Food Microb 232:7-14.

Eriksson E, Nerbrink E, Borch E, Aspan A, Gunnarsson A, 2003. Verocytotoxin-producing Escherichia coli O157:H7 in the Swedish pig population. Vet Rec 152:7127.

Fratamico PM, Bagi LK, Bush EJ, Solow BT, 2004. Prevalence and characterization of Shiga toxin-producing Escherichia coli in swine feces recovered in the National Animal Health Monitoring System's swine 2000 study. Appl Environ Microb 70:7173-8.

Honish L, Punja N, Nunn S, Nelson D, Hislop N, Gosselin G, Stashko N, Dittrich D, 2017. Escherichia coli O157:H7 Infections Associated with Contaminated Pork Products - Alberta, Canada, JulyOctober 2014. MMWR Morb Mortal Wkly Rep 65:1477-81.

ISO, 2012. International Organization for Standardization. Microbiology of food and animal feed. Real-time polymerase chain reaction (PCR)-based method for the detection of food-borne pathogens. Horizontal method for the detection of Shiga toxin-producing Escherichia coli (STEC) and the determination of O157, O111, O26, O103 and O145 serogroups. ISO Norm ISO/TS 13136:2012. International Organization for Standardization, Geneva, Switzerland.

Johnsen G, Wasteson Y, Heir E, Berget OI, Herikstad H, 2001. Escherichia coli O157:H7 in faeces from cattle, sheep and pigs in the southwest part of Norway during 1998 and 1999. Int J Food Microbiol 65:193-200.

Kaufmann M, Zweifel C, Blanco M, Blanco JE, Blanco J, Beutin L, Stephan R, 2006. Escherichia coli O157 and non-O157
Shiga toxin-producing Escherichia coli in fecal samples of finished pigs at slaughter in Switzerland. J Food Protect 69:260-6.

Lindgren SW, Melton AR, O'Brien AD, 1993. Virulence of enterohemorrhagic Escherichia coli O91:H21 clinical isolates in an orally infected mouse model. Infect Immunol 61:3832-42.

MacDonald DM, Fyfe M, Paccagnella A, Trinidad A, Louie K, Patrick D, 2004. Escherichia coli O157:H7 outbreak linked to salami, British Columbia, Canada, 1999. Epidemiol Infect 132:283-9.

Nielsen EM, Andersen MT, 2003. Detection and characterization of verocytotoxin producing Escherichia coli by automated 5' nuclease PCR assay. J Clin Microbiol 41:2884-93.

Paton AW, Ratcliff RM, Doyle RM, SeymourMurray J, Davos D, Lanser JA, Paton JC, 1996. Molecular microbiological investigation of an outbreak of hemolytic-uremic syndrome caused by dry fermented sausage contaminated with Shiga-like toxin-producing Escherichia coli. J Clin Microbiol 34:1622-7.

Perelle S, Dilasser F, Grout J, Fach P, 2004. Detection by 5 '-nuclease PCR of Shigatoxin producing Escherichia coli O26, O55, O91, O103, O111, O113, O145 and O157:H7, associated with the world's most frequent clinical cases. Mol Cell Probes 18:185-92.

Trotz-Williams LA, Mercer NJ, Walters JM, Maki AM, Johnson RP, 2012. Pork implicated in a Shiga toxin-producing Escherichia coli O157:H7 outbreak in Ontario, Canada. Can J Public Health 103:e322-6.

Tseng M, Fratamico PM, Bagi L, Delannoy S, Fach P, Manning SD, Funk JA, 2014a. Diverse virulence gene content of Shiga toxin-producing Escherichia coli from finishing swine. Appl Environ Microbiol 80:6395-402.

Tseng M, Fratamico PM, Bagi L, Manzinger D, Funk JA, 2014b. Shiga toxin-producing Escherichia coli in swine: the public health perspective. Anim Health Res Rev 8:1-13.

Villani F, Russo F, Blaiotta G, Moschetti G, Ercolini D, 2005. Presence and characterization of verotoxin producing E. coli in fresh Italian pork sausages, and preparation and use of an antibiotic-resistant strain for challenge studies. Meat Sci 70:181-8.

Williams RC, Isaacs S, Decou ML, Richardson EA, Buffett MC, Slinger RW, Brodsky MH, Ciebin BW, Ellis A, Hockin J, 2000. Illness outbreak associated with Escherichia coli O157:H7 in Genoa salami. Can Med Assoc J 162:1409-13. 